\title{
Community Service-Learning: Why Can't Canada Be More Like Mexico?
}

\author{
Victoria Calvert and Halia Valladares Montemayor
}

\begin{abstract}
In Mexico, the community service strategy and requirements for undergraduate students are both longstanding and mandated by the Mexican Constitution. Students undertake a minimum of 480 hours of service during their undergraduate degrees, which are coordinated through their universities' Social Service (SS) departments. Many Canadian universities and colleges offer community service through courses and volunteer programs; however, the practice and adoption levels vary widely. Student involvement with community partners, as represented through community service-learning (CSL) and volunteerism in Canada, are sponsored by many post-secondary institutions but are not driven by a national agenda. While, in Mexico, community service is documented at a departmental and institutional level for reporting to stakeholders and the government, in Canada, documentation of community service varies with the institutional mandate and is often sporadic or non-existent; the imperative for systematic student engagement and citizenship development has not been recognized at the national level. This research paper provides an overview of the community engagement practices in both countries, with the national patterns represented through a summative review of selected Canadian and Mexican universities. Suggestions for processes and practices for Canada are proposed based upon the Mexican model.
\end{abstract}

KEYWords service-learning, social service, institutional support, legislation, Mexico, Canada

North American post-secondary institutions have demonstrated community engagement through many venues, including co-operative education, student volunteer activities, practicums for professional programs, community-based research, and community servicelearning pedagogy (Bringle \& Hatcher, 2005). Community service-learning (CSL) is a coursebased practice that has been increasingly recognized as an effective teaching methodology which bridges academic curriculum with experiential education through community service.

Many educators recognize that CSL can offer transformational educational experiences that are necessary for deep cognitive understanding and personal development opportunities (Eyler \& Giles, 1999). While early community service-learning adopters in the United States focused on civic engagement (Astin \& Sax, 1998) and the development of ethical behaviors (Diamond, 2005) as core benefits of the pedagogy, subsequent research indicates a myriad of developmental attributes including cultural empathy and understanding (Bringle \& Hatcher, 
2010), environmental and community sustainability (De'Tray, 2005/2006; Rands \& Starik, 2009), and leadership capabilities (Brown, Trevino, \& Harrison, 2005).

Despite research demonstrating the attributes of community service-learning as a pedagogy, it is perhaps surprising that the practice has not been more widely adopted and that a Canadian national mandate for CSL does not exist. This essay seeks to draw attention to the community engagement philosophy and practice of Mexico, arguing that there is much to learn from a country that has embedded social service in undergraduate programs for almost a century. This essay provides insight regarding the community service requirements, level of adoption, institutional support, and documentation of practices in both countries. Given the broad range of community engagement, we are focusing only on course-based community engagement, typically defined as community service-learning in Canada and social service in Mexico. A literature review highlighting the effects and trends pertaining to community service-learning will lead into a brief overview of the legislation guiding educational and volunteerism practices. Canadian practices will be described, with detailed illustrations from four institutions. The community engagement patterns of Mexican post-secondary institutions and case examples will then be outlined. Finally, taking into consideration the environmental differences between the two countries, a comparison of the community engagement practices of Canada and Mexico will be drawn, with suggestions provided for Canadian academic administrators and policy-makers to ponder.

\section{Literature Review}

Experiential learning has been a cornerstone of academe for almost a century. Experiential learning pedagogies build upon Dewey's (1933) philosophy of educative experience, which recommends active learning and reflection, and include practices such as lab work, practicums, co-operative work terms, cases, community service-learning, and volunteer programs. The majority of Canadian universities active in community engagement typically offer distinct learning opportunities, employing community service-learning and volunteering activities. While definitions of CSL are contested, the literature emphasizes that community servicelearning is not volunteerism; that it applies only to projects or activities within credit courses that are based upon theoretical foundations with clear learning objectives, structured actions, and a reflective exercise (Kenworthy-U'Ren \& Peterson, 2005); and that both the student and the community partner must benefit (Govekar \& Rishi, 2007).

Generally, community service-learning methodology is flexible and encompasses a wealth of teaching options, ranging from short activities to semester-long projects; it may be teambased or individual, and it may account for a small or significant portion of the term mark (Taylor \& Pancer, 2007). The level of creativity required of the student will vary (de Janasz \& Whiting, 2009), as will the degree of project complexity and the adaptability required by students through exposure to diverse socio-economic conditions or cultures (Hartel, 2010). In an anthology of community service-learning, Beatty (2010) identifies three common models: 1) the professional model, which focuses on career training with cognitive learning goals; 2) the civic engagement model, which focuses on developing active and engaged citizens; 
and 3) the social change model, which focuses on empowerment and social justice. Eyler et al. (1999) suggest that four criteria need to be satisfied for the community service-learning experience to be successful for the student: 1) personal and interpersonal development; 2) greater understanding and application of community service curriculum; 3) the transformation of perspective; and 4) the development of citizenship understanding and behaviors. Many proponents of community service-learning would also add that projects should enhance the sustainability of the community partner (Calvert, 2012).

Numerous empirical articles have established the credibility of community servicelearning as an effective pedagogy for developing students' cognitive ability (Eyler et al., 1999), empathy (Bloom, 2008; Lundy, 2007), life skills (Astin et al., 1998), civic engagement (Einfeld \& Collins, 2008), teamwork (Govekar et. al., 2007), and motivation to study (Flournoy, 2007). Outcomes for students have been linked to the development of leadership, communication, and interpersonal skills (Tomkovick, Lester, Flunker, \& Wells, 2008), and the development of corporate social responsibility values (Lester, Tomkovick, Wells, Flunker, \& Kickul, 2005).

Three nascent community service-learning research themes are sustainability, social entrepreneurship, and international engagement, discussed in brief below. Sustainability is a broad topic that encompasses not only social, economic, cultural, and environmental factors, but the viability of community organizations. Professors develop community service-learning projects that contribute to sustainability with an emergent recognition that students become passionate about the cause when they are intellectually and emotionally engaged (Shrivastava, 2010), and furthermore, that they will become proponents of change, thereby facilitating community development (Dana, Murphy \& Callaghan, 2010). Students engaged in community service-learning projects also ease the financial burden imposed by cash-strapped governments and donors (Eisner, Grimm, Maynard \& Washburn, 2009). A study by Kenworthy-U'Ren (2008) supports community service-learning as a "best practice" for student experience and community sustainability.

The energy, creativity, and skills displayed by students through community service-learning may also be directed towards students' development of social entrepreneurship attributes. Gregory Dees (1998) describes social entrepreneurs as agents of change who contribute to the organizational sustainability of non-profit organizations through creative entrepreneurial solutions. Universities are building programs to develop social entrepreneurs (Sheil \& Bahk, 2010; Tracey \& Phillips, 2007), wherein students create or assist ventures that require innovative solutions, while pursuing a social mission (Calvert, Jagoda, \& Jensen, 2011). Mount Royal University, for example, offers a range of courses whereby student projects support nonprofit organizations or enhance the efficiency of organizations that promote social benefit, such as organic food distributors or transportation firms employing restaurant waste as fuel.

International service-learning is increasingly popular both as an activity and as a research topic. Popular topics of investigation include: the impact of service-learning on community partners; ethical issues, such as the power dynamics between wealthy northern countries and southern countries; and the complexities of cultural empathy and understanding. Research indicates international service-learning student experiences are transformational (Bringle et 
al., 2010), enhance cultural sensitivity (Borden, 2007), increase diversity awareness (de Janasz et al., 2009), and contribute towards the development of global citizens (Battistoni, Longo, \& Jayanandhan, 2009). A recent study provided empirical evidence of the effectiveness of CSL in the development of cultural sensitivity (Holsapple, 2012), which is increasingly important in light of the growth of diversity across global populations (Hartel, 2010; Zlotkowski, 1996).

\section{Educational Mandates}

Within the federal system of shared powers, Canada's Constitution Act of 1867 provides that education is under provincial and territorial jurisdiction; as such, there is no federal department of education and no integration at a national level. Provincial ministries of education are responsible for the organization, delivery, and assessment of education at the elementary and secondary levels, for technical and vocational education, and for postsecondary education. Some jurisdictions have separate departments or ministries, with one having responsibility for elementary and high school education, and another for postsecondary education and skills training (CMEC, "Education in Canada," n.d.).

Among Canadian provincial jurisdictions, significant differences in curriculum, assessment, and accountability policies exist to address the diverse geography, history, language, culture, and specialized needs of the populations served. While the federal system does not enforce national standards, there are higher education and professional associations with that mandate. There are several national educational associations, including Universities Canada (formerly called the Association of Universities and Colleges of Canada or AUCC), which promotes the interests of higher education, and whose members represent many of the postsecondary institutions in Canada. The organization provides a framework that requires institutions to adhere to set principles of quality assurance and transferability for accredited courses, as verified through audits every five years ("How Quality Assurance," n.d.). Another national organization, the Council of Ministers of Education, Canada (CMEC), is an intergovernmental forum, of which all provinces and territories are members, whose mandate includes: discussion of policy issues, promotion of initiatives of mutual interest, cooperation with other national education organizations, and the representation of the education interests of the provinces and territories internationally ("About CMEC," n.d.). Statistics Canada indicates a national population of 35 million people, of which 2,034,957 were students attending post-secondary institutions in Canada during the 2015-2016 academic year (2016). 97 postsecondary institutions are members of Universities Canada (Universities Canada, n.d.). While Universities Canada and CMEC provide frameworks and guidance on curriculum, they do not provide guidelines or requirements for c ommunity service-learning.

The fragmented Canadian approach to community engagement contrasts with the Mexican practice of required community engagement, which emerged during the post-revolutionary period of 1910 to 1917. The revolution forged a particular philosophy for higher education, which proposes that university graduates should have a background in the sciences and humanities that demonstrates sympathy with the working class. The constitutional requirement for university graduates to participate in social service reflects a national imperative to solve 
problems pertaining to low income populations, but also the need to establish a Mexican educational identity (Cornejo, 1992). Of the Mexican population of 120 million in 2015, 2.9 million were students registered in 2,359 post-secondary institutions. ${ }^{1}$

In 1936, the first group of students participating in social service were from the Faculty of Medicine at Universidad Nacional Autónoma de México/National Autonomous University of Mexico (UNAM); they provided health services to a community in Atlixco, Puebla. Upon completing six years of medical studies, the students were required to provide six months of services in a community without a medical doctor (Cornejo, 1992). Afterwards, social service was instituted for all faculties at UNAM. However, it was not until 1942 that social service was adopted through the Mexican Constitution (Cornejo, 1992). The Mexican Constitution stipulates social service for undergraduate students in Articles 3 and 5, and the National Congress passed a regulatory legislation entitled "Ley Reglamentaria del articulo 5 constitucional, relativa al ejercicio de las profesiones en el Distrit Federal' (Ramirez, 2012). The ruling indicates that social service is to be either modestly paid or on a volunteer basis; it is for the benefit of the society and the state; it is a requirement to obtain a degree; it should not be performed for less than six months or more than two years (universities typically translate the requirement in their internal policies as a minimum of 480 hours); and universities are responsible for the students while they are performing social service activities (Ramirez, 2012; Universia, 2014).

During the 1945 to 1980 period, Mexican students primarily performed social service to government and health organizations. In 1981, the Commission to Coordinate the Social Service of the Students of Post-Secondary Institutions (COSSIES) was established; it developed the bylaws that provide the basis for all current rulings on the topic (Cornejo, 1992). In 1990, COSSIES was replaced by the Programa Nacional de apolyo al Servicio Social/ National Support Programme for Social Service (PRONAS), which provides aid, advice, and information to universities (UJED, 2014).

Whereas a national mandate for community service-learning in Canadian post-secondary institutions cannot be legislated through the federal government, the universal Mexican requirement resulted from a federal mandate and is supported through legislation, longstanding practices, and national organizations. While we recognize Canada cannot model CSL after the Mexican approach due to its educational structure, we would like to provide insight into a national CSL practice that is integrated throughout every post-secondary institution. We believe that it is worthwhile reflecting on how such practices could be adopted in the Canadian context, despite constitutional limitations.

\section{An Overview of Community Service-Learning at Post-Secondary Institutions in Canada}

Community service-learning has been adopted by more than forty Canadian universities and colleges as a teaching and community outreach strategy, as indicated either through institutional websites or affiliations with the Canadian Alliance for Community Service-Learning (CACSL).

\footnotetext{
${ }^{1}$ See http:// ciees.edu.mx/index.php/publicaciones/estadistica
} 
Academic institutions vary in their commitment to community engagement, which may be assessed by measuring several factors, identified below. The need for institutional support has been a theme expressed by faculty, community partners, and researchers for many years. Barbara Holland (2001) explored the structure necessary for successful community service-learning projects and stakeholder outcomes, identifying structured assessment, solid communication with community partners, and institutional support as contributing factors. The work required to develop community partner relationships (Calvert, 2012), create and assess projects that fit both time constraints and curriculum requirements (Calvert, 2011), and address perceived risks implicit in such projects (Andrews, 2007) highlights the critical need for institutional support. The degree and range of institutional commitment and support may be demonstrated through the following markers: a dedicated community engagement centre; cocurricular recognition of community engagement; an academic or strategic plan that reflects commitment to engagement; and long-term community partnerships, each detailed below.

First, institutional support may be demonstrated through a community engagement centre: the level of staffing, funding, and resource materials for students and faculty offered through a dedicated centre provides a clear indication of the importance attached to community engagement. Whereas some institutions host community service-learning activities through Learning Services or Student Affairs, others have developed stand-alone community engagement centres which include community service-learning. Centres typically provide materials for faculty, students, and administrators to meet with potential community partners, establish relationships, and identify projects. Some universities, such as the University of Toronto, host yearly faculty development institutes to share community service-learning practices. Dedicated staffing for community service-learning and community engagement ranges from nine full-time staff at the Centre for Community Engaged Learning, where administrators are assigned to academic departments to assist in the design and support of community engagement, to institutions such as Queen's University, where only one designated faculty member or administrator is assigned to community engagement on a part-time basis or as part of their other duties. There are some institutions, such as Thompson Rivers University and the University of Lethbridge, that do not publish any involvement in community engagement; individual faculty or programs may conduct community service-learning, but such participation is not publicized at the institutional level. Other institutions, such as the University of Ottawa, have extensive and visible interface opportunities with the community through efficient databases that match students to community partners for volunteer activities, and faculty to community partners for community service-learning projects. ${ }^{2}$

Co-curricular recognition is another gauge of institutional support. Several institutions, including the University of Alberta, Mount Royal University, and the University of Ottawa, offer a certificate of recognition for students who complete a significant number of community service-learning and/or volunteer activities. The certificate typically requires either three or

\footnotetext{
${ }^{2}$ We gratefully acknowledge the information provided in an interview in 2015 by Mona Hafez, Manager, Community Engagement, Centre for Global and Community Engagement, University of Ottawa.
}

Engaged Scholar Journal: Community-Engaged Research, Teaching, and Learning 
more courses with community service-learning projects embedded in the curriculum, or a combination of coursework and volunteer activities that are recorded by the community partner and the institution. However, because the documentation of student engagement is cumbersome and requires institutionally accepted practices and systems, co-curricular recognition is not widespread, with many institutions recognizing community service-learning activities only at the course level.

Strategic planning is another important activity that registers commitment. Institutional articulation of community engagement as a component of strategic planning often aligns with the adoption of a high level of community engagement through volunteer programs and course-based projects. Statements of commitment to community engagement are common for some universities, but they are not necessarily translated into funding for a community engagement centre or staff. In order to express genuine commitment to engagement, institutional mission statements must flow into community engagement practices, as at the University of Alberta, where as part of the Academic Plan For the Public Good, the University articulates its "commitments to learning, discovery, and citizenship, and to connecting communities" ("Campus sustainability," n.d.).

Finally, an institution's support for long-term community partnerships is a key measure of its commitment to engagement. The alignment of goals for faculty, the community partner, and the academic institution is challenging, with ongoing institutional commitment necessary for fostering collaborative programs (Brundiers, Wiek \& Redman, 2010). Duffy (2010) cites the danger of "one-shot" projects which provide a brief burst of assistance to community partners but that drain resources, such as personnel, and do not contribute the partners' ongoing sustainability. The development of true long-term dyadic relationships between faculty and community organizations is perceived to be a critical contribution not only to effective and rewarding learning experiences for students, but also to the sustainability of community partners and the deeper engagement of students in social interventions and social activism (Rasch, Murphy \& Callaghan, 2010). The selection of partners with a focus on potential long-term relationships reflects a mature community service-learning practice and a high level of institutional and faculty commitment (Calvert, 2012). While many academic institutions indicate their support for sustainability through community engagement, evidence of long-term partnership development as articulated in articles or public information such as websites is lacking, reflecting the developmental nature of community service-learning practices at the institutional level in Canada.

When examining the Canadian community service-learning landscape through the above criteria, the lack of consistency between institutions is evident: the articulation of institutional support and practice varies from a high level of visibility with extensive resources and support for faculty, students, and community partners, to no indication of faculty or institutional community engagement. Further, there is a profound lack of measurable deliverables at the institutional and national level. While a few institutions provide some indication of the level of engagement by identifying the number of students and faculty engaged in community service-learning through coursework, the number of hours of community engagement, and 
the number of community partners, the reporting is summative, and the impact upon students and community partners is typically not assessed or conveyed. A sampling of the community service-learning practices at four Canadian institutions through a review of their websites is provided in Table 1. While we recognize that there are additional colleges and universities pursuing community engagement at a course and institutional level, a detailed survey of all practicing institutions is beyond the scope of this paper.

\section{Table 1. An overview of the community service-learning practices of four Canadian universities}

\begin{tabular}{|c|c|c|}
\hline Criteria $^{3}$ & University of Alberta & University of Ottawa \\
\hline $\begin{array}{l}\text { Community } \\
\text { engagement centre }\end{array}$ & $\begin{array}{l}\text { Active for over a decade, with a } \\
\text { base in the Faculty of Arts and an } \\
\text { active advisory board of faculty and } \\
\text { community partners. }\end{array}$ & $\begin{array}{l}\text { The Michaëlle Jean Centre for } \\
\text { Global and Community Engagement } \\
\text { has been active for over a decade. } \\
\text { Community service-learning and } \\
\text { volunteerism are equally supported } \\
\text { and recognized. }\end{array}$ \\
\hline Staff & $\begin{array}{l}\text { Staff includes a director, faculty, } \\
\text { and administrators who provide } \\
\text { one-stop service and materials for } \\
\text { stakeholders. }\end{array}$ & $\begin{array}{l}\text { The director, community } \\
\text { coordinators, and student researchers } \\
\text { and facilitators support community } \\
\text { outreach. }\end{array}$ \\
\hline $\begin{array}{l}\text { Measurement } \\
\text { of community } \\
\text { service-learning and } \\
\text { volunteerism }\end{array}$ & $\begin{array}{l}\text { Reports are provided periodically; } \\
\text { the website indicates } 1000 \text { students, } \\
60 \text { courses, and } 150 \text { community } \\
\text { partners per annum. With a } \\
\text { student population of } 39,000 \text {, the } \\
\text { participation rate is estimated to be } \\
3 \% \text {. }\end{array}$ & $\begin{array}{l}\text { An annual report is provided for } \\
\text { community service-learning and } \\
\text { volunteer activities. In } 2015 \text {, over } \\
2,257 \text { students in } 148 \text { courses were } \\
\text { involved in community service- } \\
\text { learning; almost 3,000 more students } \\
\text { volunteered. }\end{array}$ \\
\hline $\begin{array}{l}\text { Student or faculty } \\
\text { recognition }\end{array}$ & $\begin{array}{l}\text { The Certificate in Community } \\
\text { Engagement and Community } \\
\text { Service-Learning is awarded } \\
\text { to students completing one } \\
\text { community service-learning course } \\
\text { and three courses with community } \\
\text { service-learning components as well } \\
\text { as a volunteer activity. }\end{array}$ & $\begin{array}{l}\text { Awards for excellence in service } \\
\text { learning by students, faculty, and } \\
\text { partners. A certificate is awarded to } \\
\text { students completing three community } \\
\text { service-learning or volunteer } \\
\text { activities. Scholarships are provided } \\
\text { for local and field school projects. }\end{array}$ \\
\hline $\begin{array}{l}\text { Academic or strategic } \\
\text { plan }\end{array}$ & $\begin{array}{l}\text { The Centre's mission reflects the } \\
\text { philosophy of the Academic Plan. }\end{array}$ & $\begin{array}{l}\text { The Centre supports the university } \\
\text { vision. }\end{array}$ \\
\hline
\end{tabular}

\footnotetext{
${ }^{3}$ Referenced from the University of Alberta ("Community service-learning," n.d.); the University of Ottawa ("Community service learning," n.d.); the University of British Columbia ("Learning exchange," n.d.); and Mount Royal University ("Community service learning," n.d.). Data gathered in 2015. See reference list for full citation information.
} 


\begin{tabular}{|c|c|c|}
\hline Website & $\begin{array}{l}\text { Fully developed with materials for } \\
\text { faculty, students, and community } \\
\text { partners. A database identifies } \\
\text { community service-learning } \\
\text { courses. }\end{array}$ & $\begin{array}{l}\text { Fully developed with reference sheets } \\
\text { and handbooks for stakeholders. } \\
\text { An extensive database documents } \\
\text { activities and facilitates volunteer } \\
\text { placements. }\end{array}$ \\
\hline $\begin{array}{l}\text { Specially designed } \\
\text { community service- } \\
\text { learning courses or } \\
\text { volunteer activities }\end{array}$ & $\begin{array}{l}\text { Courses specifically designed as } \\
\text { CSL offer an in-depth exploration } \\
\text { of theories and practices of civic } \\
\text { engagement. Some have an industry } \\
\text { focus or require community } \\
\text { service-learning or volunteer } \\
\text { experience. }\end{array}$ & $\begin{array}{l}\text { Staff at the centre work with faculty } \\
\text { to incorporate community service- } \\
\text { learning into their course curriculum. } \\
\text { Extensive volunteer activities are } \\
\text { available to students through the } \\
\text { database. }\end{array}$ \\
\hline $\begin{array}{l}\text { International service- } \\
\text { learning }\end{array}$ & $\begin{array}{l}\text { International field schools enable } \\
\text { students to achieve a certificate in } \\
\text { global citizenship. }\end{array}$ & $\begin{array}{l}\text { International volunteer activities and } \\
\text { community service-learning courses } \\
\text { are offered. }\end{array}$ \\
\hline Support for research & $\begin{array}{l}\text { A community service-learning } \\
\text { research group was established in } \\
2013 .\end{array}$ & $\begin{array}{l}\text { Professors work with staff from the } \\
\text { centre on projects and are active in } \\
\text { community service-learning research } \\
\text { and publishing. }\end{array}$ \\
\hline Criterion & University of British Columbia & Mount Royal University \\
\hline $\begin{array}{l}\text { Community } \\
\text { engagement centre }\end{array}$ & $\begin{array}{l}\text { Founded in } 1999 \text { as a catalyst for } \\
\text { social innovation and student } \\
\text { engagement. Strategic growth and } \\
\text { programs are supported by the } \\
\text { institution and donations. }\end{array}$ & $\begin{array}{l}\text { Founded in } 2013 \text { at the institutional } \\
\text { level, recognizing over twenty years } \\
\text { of student and faculty community } \\
\text { engagement in course work. } \\
\text { Numerous workshops on community } \\
\text { service-learning research and } \\
\text { curriculum are offered. }\end{array}$ \\
\hline Staff & $\begin{array}{l}\text { A director and specialized staff } \\
\text { offer workshops and support } \\
\text { to faculty and community } \\
\text { organizations. }\end{array}$ & $\begin{array}{l}\text { One faculty member provides } \\
\text { teaching and research support to } \\
\text { faculty for community service- } \\
\text { learning activities on a part-time } \\
\text { basis. }\end{array}$ \\
\hline $\begin{array}{l}\text { Measurement of } \\
\text { community service- } \\
\text { learning courses and } \\
\text { volunteer activities }\end{array}$ & $\begin{array}{l}\text { The most recent public reporting } \\
\text { from } 2010 \text { indicated } 1,342 \text { students } \\
\text { worked with a total of } 77 \text { NPOs, } \\
121 \text { public schools, and } 10 \text { small } \\
\text { businesses. }\end{array}$ & $\begin{array}{l}\text { During the } 2015-2016 \text { academic year, } \\
\text { over } 2,500 \text { students provided } 300,000 \\
\text { hours of community service-learning } \\
\text { with over } 450 \text { community partners. } \\
\text { Twenty five percent of the student } \\
\text { population is engaged in community } \\
\text { service-learning. }\end{array}$ \\
\hline
\end{tabular}




\begin{tabular}{|c|c|c|}
\hline $\begin{array}{l}\text { Student or faculty } \\
\text { recognition }\end{array}$ & $\begin{array}{l}\text { Student stories regarding their } \\
\text { experiences are shared on the UBC } \\
\text { website. }\end{array}$ & $\begin{array}{l}\text { A citation in community service- } \\
\text { learning is awarded to students } \\
\text { completing three community } \\
\text { service-learning designated courses; } \\
\text { approximately } 300 \text { students qualify } \\
\text { annually. }\end{array}$ \\
\hline $\begin{array}{l}\text { Academic or strategic } \\
\text { plan }\end{array}$ & $\begin{array}{l}\text { In } 2011 \text { the strategic direction } \\
\text { of the Community Engagement } \\
\text { Centre was updated. }\end{array}$ & $\begin{array}{l}\text { The Academic Plan supports } \\
\text { community engagement and } \\
\text { experiential learning. }\end{array}$ \\
\hline Website & $\begin{array}{l}\text { Provides some information } \\
\text { for stakeholders; a database } \\
\text { provides community engagement } \\
\text { opportunities for students. }\end{array}$ & $\begin{array}{l}\text { Preliminary stages with curriculum } \\
\text { and research references for } \\
\text { faculty; no material for students or } \\
\text { community partners. }\end{array}$ \\
\hline $\begin{array}{l}\text { Specially designed } \\
\text { community service- } \\
\text { learning courses or } \\
\text { volunteer activities }\end{array}$ & $\begin{array}{l}\text { Community service-learning, } \\
\text { volunteerism, and community } \\
\text { research are blended into the UBC } \\
\text { definition of community-based } \\
\text { experiential learning. Staff work } \\
\text { with faculty and students to develop } \\
\text { engagement opportunities. }\end{array}$ & $\begin{array}{l}\text { Several community service-learning } \\
\text { courses are being designed as } \\
\text { introductory general education. } \\
\text { Over } 40 \text { courses, some with up to } 16 \\
\text { sections annually, have community } \\
\text { service-learning projects with long- } \\
\text { standing community partners. }\end{array}$ \\
\hline $\begin{array}{l}\text { International } \\
\text { community service- } \\
\text { learning }\end{array}$ & $\begin{array}{l}\text { There is an emphasis on fostering } \\
\text { global citizenship through field } \\
\text { schools with long-standing } \\
\text { partnerships and funding for } \\
\text { students. }\end{array}$ & $\begin{array}{l}\text { International field schools with a } \\
\text { strong community service-learning } \\
\text { component have been developed. } \\
\text { While some are two weeks long, } \\
\text { others extend over four weeks and } \\
\text { entail several courses. }\end{array}$ \\
\hline Research Support & Not identified. & $\begin{array}{l}\text { A research group of } 14 \text { faculty } \\
\text { publish and share research agendas. }\end{array}$ \\
\hline
\end{tabular}

\section{An Overview of Post-Secondary Institutions in Mexico}

At the outset of this section, we gratefully acknowledge the support provided by Elena Montemayor Rodriguez, Director of Teaching Profession at Universidad Autonoma de Tamaulipas (UAT). Elena used her connections or guanxi to obtain valuable information about community service in Mexico not available to the public or in online sources.

Social service in Mexico is an integral part of the undergraduate student experience; organizing and monitoring community engagement is a priority for academic institutions, with faculty and administrators across the institution involved in the process. It is neither community service-learning nor volunteerism, but rather combines the two practices; students apply their academic training in required community engagement outside of academic classes.

In addition to the support provided by the Programa Nacional de apolyo al Servicio Social/National Support Programme for Social Service (PRONAS), universities in Mexico are members of the Asociación Nacional de Universideades e Institutciones de Educación 
Superior (ANUIES), which is a collaborative association for social service that has supported research and data analysis since 1970. ANUIES aims to create an academic space for reflective practices, analysis, and the promotion of research pertaining to social service. Further, it provides awards and diploma programs for innovative programs and the management of social service for administrators, and also organizes national and regional meetings (Escamilla, 2013).

ANUIES has organized thirty-one national and five international conferences based in Mexico related specifically to social service, with varied universities serving as hosts. According to Lopez et al. (1997), the objective of the conferences is to discuss issues and strategies pertaining to social services, including logistical issues, university curriculum, student training, the development of administrative processes, and optimization of the student experience. During the conferences held during the 1978 to 1993 period, a total of thirty-nine proposals related to social service were reviewed, resulting in eighteen strategic initiatives and operational strategies that required nation-wide adoption. This included the 1986 creation of an interuniversity commission for social service that integrated all public universities, and the provision of funding to train university personnel in charge of social service. Research papers related to social service training, program design, and impact are prevalent at these conferences.

\section{Examples of Social Service in Mexico}

At UNAM, Latin America's largest university and the oldest post-secondary institution in Mexico, social service is coordinated by the General Directorate of Orientation and Educational Services (GDOSE). There is a Vice-Directorate of Social Service, with departments overseeing registration and program activities. In addition, social service activities are regulated by department-based faculty committees that establish requirements through internal policies and administer interdisciplinary and multidisciplinary programs. These faculty committees are responsible for regulating, coordinating, supervising, and evaluating the social service activities for students, and for providing documentation when requirements are fulfilled (UNAM, 2014). UNAM has more than 4,000 registered social service programs in their database, which is available through a centralized social service website. Students can research programs that have been approved by their faculty and decide the best place to apply their specific degree knowledge (UNAM, 2003). The programs of study with the greatest demand from community partners include: law, social work, psychology, architecture, sociology, management, and accounting. The types of activities the students are required to perform vary from activities directly related to their field of study to simple administrative tasks that are skill-specific.

UNAM provides orientation workshops to students prior to their service, as well as personalized advising thereafter. The social service website informs students about administrative requirements and offers an automated database that identifies potential community partners. The university sends emails and electronic postcards to update students regarding social service information sessions, and a week of specialized training sessions is offered each semester (UNAM, 2014).

At the Autonomous University of Tamaulipas (UAT), the management of social services 
is similar to that at UNAM, with a comprehensive administrative structure including a general director, the support of two divisions for planning and management, three sub-directors of social service (one for each of the campuses in the province), coordinators for each faculty, staff to update the website, and a coordinator for social service teams. At UAT, students have the option of performing social service individually or in teams. Students in medicine, nursing, and dentistry are required to provide one year of social service; all other faculties require only 480 hours of service. Students may perform the service at government institutions, non-profit institutions, agricultural centres, educational institutions, or for companies. While medical students are required to have $97 \%$ of their courses completed prior to service, all other programs require only a $60 \%$ completion rate. To ensure that standards for social service are attained, random visits to audit partner institutions and students are perfor. Students are required to submit reports, a work program, an acceptance letter from the community partner, and other documents into an online system (UAT, 2014a; UAT, 2014b; C. Ibarra Gonzalez, personal communication, August 21, 2014).

A sampling of the social service practices for the aforementioned Mexican universities, both with a long-standing history of administrative skill in the area, is provided in Table 2. All colleges and universities pursue social services to a similar extent due to legislative requirements, and as such have similar processes and systems. A detailed survey of additional institutions would provide only minor incremental insight into social service practices and is beyond the scope of this paper.

Table 2. An overview of the social service practices at two Mexican universities ${ }^{4}$

\begin{tabular}{|l|l|l|}
\hline Criteria $^{5}$ & $\begin{array}{l}\text { National Autonomous } \\
\text { University of Mexico (UNAM) }\end{array}$ & $\begin{array}{l}\text { Autonomous University } \\
\text { of Tamaulipas (UAT) }\end{array}$ \\
\hline Social service centre & $\begin{array}{l}\text { The first social service activity } \\
\text { was conducted in 1936, with full } \\
\text { adoption in the 1940s. The centre } \\
\text { is under a department called } \\
\text { DGOSE. }\end{array}$ & $\begin{array}{l}\text { Centre created in the 1970s at the } \\
\text { founding of the university. }\end{array}$ \\
\hline Staff & $\begin{array}{l}\text { Twelve staff provide services } \\
\text { through the centre, with one } \\
\text { professor assigned to social service } \\
\text { in each faculty. }\end{array}$ & $\begin{array}{l}\text { The centre has 15 positions, with } \\
\text { an additional 26 coordinators, a } \\
\text { minimum of one representative for } \\
\text { each faculty. }\end{array}$ \\
\hline
\end{tabular}

\footnotetext{
4 Table self-developed from information obtained from both universities' webpages, other secondary data sources, and documents provided by UAT senior administration, all listed in the references.

${ }^{5}$ Referenced from http://www.dgoserver.unam.mx/ ; http://www.siss.uat.edu.mx/
} 


\begin{tabular}{|c|c|c|}
\hline Measurement & $\begin{array}{l}\text { Reports are provided periodically; } \\
\text { the website indicates } 324 \text { programs } \\
\text { in } 2009 \text { and } 322 \text { in } 2010 \text {, with } \\
\text { an estimated } 10,700 \text { students } \\
\text { participating annually. }\end{array}$ & $\begin{array}{l}\text { Reports are per faculty, as well as } \\
\text { a total for the campus. Students } \\
\text { prepare monthly reports and a final } \\
\text { report. The directorate provides } \\
\text { reports every six months to partner } \\
\text { institutions, the university's quality } \\
\text { department, and the university } \\
\text { president. An estimated } 3,600 \\
\text { students participate annually. }\end{array}$ \\
\hline $\begin{array}{l}\text { Student or faculty } \\
\text { recognition }\end{array}$ & $\begin{array}{l}\text { There is a yearly award dedicated } \\
\text { to social service for each program. } \\
\text { The objective is to recognize } \\
\text { students who had distinguished } \\
\text { participation with social impact, } \\
\text { and contributed to the economic, } \\
\text { social, and educational level of the } \\
\text { country. Recipients receive a silver } \\
\text { medal and a certificate. }\end{array}$ & $\begin{array}{l}\text { Students get a final letter stating } \\
\text { that they fulfill the requirements for } \\
\text { social service. Awards for students } \\
\text { or faculty are not mentioned. }\end{array}$ \\
\hline $\begin{array}{l}\text { Academic or strategic } \\
\text { plan }\end{array}$ & $\begin{array}{l}\text { The Centre's mission reflects the } \\
\text { national and university legislation } \\
\text { and General Social Service } \\
\text { Regulation (1985). }\end{array}$ & $\begin{array}{l}\text { The Centre's mission reflects } \\
\text { the national, state, and university } \\
\text { legislation. }\end{array}$ \\
\hline Website & $\begin{array}{l}\text { Fully developed with materials } \\
\text { for social service coordinators, } \\
\text { students, and community partners. }\end{array}$ & $\begin{array}{l}\text { Fully developed with materials for } \\
\text { social service coordinators, students, } \\
\text { and community partners. Contains a } \\
\text { database system. }\end{array}$ \\
\hline $\begin{array}{l}\text { Specially designed } \\
\text { social service activities }\end{array}$ & $\begin{array}{l}\text { The centre provides orientation } \\
\text { workshops and personalized and } \\
\text { ongoing advising for students and } \\
\text { community partners. }\end{array}$ & $\begin{array}{l}\text { The social service coordinator for } \\
\text { each faculty provides an orientation } \\
\text { course to students before they start } \\
\text { their service. Additional services are } \\
\text { available from the main centre. }\end{array}$ \\
\hline $\begin{array}{l}\text { International social } \\
\text { service }\end{array}$ & $\begin{array}{l}\text { The social service legislation } \\
\text { restricts foreign activities. }\end{array}$ & $\begin{array}{l}\text { The social service legislation restricts } \\
\text { foreign activities. }\end{array}$ \\
\hline Support for Research & $\begin{array}{l}\text { Not mentioned at the university } \\
\text { level. }\end{array}$ & $\begin{array}{l}\text { Faculty conduct research in social } \\
\text { service and participate in national } \\
\text { conferences. }\end{array}$ \\
\hline
\end{tabular}

\section{The Differences: What Can Be Learned}

According to a report from UNAM (2014), one of the biggest concerns pertaining to social service in Mexico is that the students do not perceive a relationship between the social service 
mandate and the activities they are assigned. For example, the community partners assigned as supervisors may ask students to do bureaucratic errands, instead of asking them to perform activities through which they could apply their discipline-specific knowledge. Some consider the social service programs to be inefficient or insufficient, and reflective of a political agenda that should not be mandated. Mexico could attain better student buy-in for social service by educating students on the importance of these activities, indicating the benefits for them and their community partners, and for the economic and social progress of the country. Furthermore, the current restrictive nature of the legislation does not encourage or recognize international social service; as such, opportunities for students are discouraged, resulting in a more limited adoption of a global citizenship philosophy than countries that encourage international service-learning.

International awareness of the social service practices of Mexico has been limited due to two factors: publications are in Spanish and not available in English translations, and professors researching the impact and processes do not typically publish in journals due to restrictive publication practices. Mexican conferences require full papers, and ISBN numbers are assigned to accepted papers. As such, while many faculty attend and present research at conferences, their work will only be shared with those attending the conference and may not be submitted for wider distribution through journal publication. The sharing of research pertaining to social service with community service-learning scholars would be most beneficial, but is unfortunately rare. We understand that similar barriers may exist for community servicelearning scholars in Latin America, further contributing to the lack of awareness outside the region of innovative practices, processes, policies, and strategies. The publication of this article extends an invitation for scholars to explore the implications of these restrictions further.

Academics and administrators in Canada would benefit from a national conversation on the role of community service-learning in post-secondary education. The ad hoc method of sponsoring and administrating community service-learning in Canada contributes to community partner confusion and negates a consistent message regarding the effectiveness and moral imperative of promoting community engagement in academic institutions. While the social service practice in Mexico could be refined through additional information-sharing with students and methods to ensure the fit between student skills and community partners, the concept of a national agenda for student service is appealing. 
Table 3. Highlighting the differences

\begin{tabular}{|c|c|c|}
\hline Category & Canada & Mexico \\
\hline $\begin{array}{l}\text { Community engagement } \\
\text { legislation }\end{array}$ & $\begin{array}{l}\text { Neither national nor provincial } \\
\text { legislation exists regarding } \\
\text { community service-learning } \\
\text { at the post-secondary level. } \\
\text { Some universities have adopted } \\
\text { policies of support. }\end{array}$ & $\begin{array}{l}\text { Article } 5 \text { of the Mexican } \\
\text { Constitution requires social } \\
\text { service as a condition of } \\
\text { graduation, as does the } \\
\text { individual legislation of each } \\
\text { university. }\end{array}$ \\
\hline $\begin{array}{l}\text { Organization commitment, } \\
\text { processes, and administration }\end{array}$ & $\begin{array}{l}\text { While several universities have } \\
\text { allocated staff and developed } \\
\text { systems and measurement } \\
\text { processes, most have limited } \\
\text { to no support and do not } \\
\text { document activities. }\end{array}$ & $\begin{array}{l}\text { All post-secondary institutions } \\
\text { are required to manage the } \\
\text { engagement process, including } \\
\text { bylaws, administrators, and } \\
\text { systems to document student } \\
\text { activities at a university and } \\
\text { departmental level. }\end{array}$ \\
\hline Level of faculty involvement & $\begin{array}{l}\text { Faculty adoption varies } \\
\text { dramatically: typically, nursing } \\
\text { schools and some professional } \\
\text { programs designate faculty to } \\
\text { organize community service- } \\
\text { learning projects. }\end{array}$ & $\begin{array}{l}\text { At least one professor per } \\
\text { faculty or school is designated to } \\
\text { be the social service coordinator } \\
\text { by the dean. }\end{array}$ \\
\hline Level of student involvement & $\begin{array}{l}\text { Data has not been collected at a } \\
\text { national level. In the universities } \\
\text { with the highest level of } \\
\text { adoption } 25 \% \text { of students } \\
\text { participate; in most universities, } \\
\text { the level would be less than } 5 \% \text {, } \\
\text { and in some less than } 1 \% \text {. }\end{array}$ & $\begin{array}{l}\text { All students are required to } \\
\text { participate due to graduation } \\
\text { requirements. An estimated } \\
508,953 \text { students provide } \\
244,297,000 \text { hours of social } \\
\text { service per year. } \\
\text { According to ANUIES } \\
(2012) \text { in } 2010-2011 \text {, } \\
401,074 \text { students graduated; } \\
\text { therefore, } 192,515,520 \text { hours } \\
\text { of community service were } \\
\text { provided that year. Students } \\
\text { conduct much of the service } \\
\text { in the final two years of their } \\
\text { degree, and in some degrees } \\
\text { only after } 97 \% \text { of their degree } \\
\text { course work. }\end{array}$ \\
\hline
\end{tabular}

\footnotetext{
${ }^{6}$ We calculated the number of students engaged in social service yearly by dividing the number of registered students by the percentage that graduate, divided by two as students complete the social service requirement after $60 \%$ of their curriculum is completed during the last two years of their degree: $((3,161,200 \times .322) / 2=508,953) \times 480$ hours $=$ $244,297,536$ hours annually.
} 


\begin{tabular}{|c|c|c|}
\hline $\begin{array}{l}\text { Nature of community } \\
\text { relationships }\end{array}$ & $\begin{array}{l}\text { Some universities co-ordinate } \\
\text { community service-learning } \\
\text { projects for faculty through a } \\
\text { community service-learning or } \\
\text { community engagement centre } \\
\text { and maintain a database. In } \\
\text { many universities, individual } \\
\text { professors organize projects } \\
\text { with community partners. }\end{array}$ & $\begin{array}{l}\text { The partner relationship } \\
\text { varies by profession: } \\
\text { each departmental liaison } \\
\text { representative organizes student } \\
\text { and community projects. }\end{array}$ \\
\hline $\begin{array}{l}\text { Level of volunteerism in } \\
\text { society }\end{array}$ & $\begin{array}{l}\text { In } 2010,47 \% \text { of Canadians } \\
\text { contributed their time to } \\
\text { charities and non-profits for } \\
2.07 \text { billion hours, which } \\
\text { is equivalent to just under } \\
1.1 \text { million full-time jobs } \\
\text { (Vézina \& Crompton, 2012). }\end{array}$ & $\begin{array}{l}\text { In Mexico } 16.5 \% \text { of the } \\
\text { population (INEGI, 2012) have } \\
\text { at least some level of higher } \\
\text { education, and as such have } \\
\text { participated in social service. } \\
\text { Volunteerism is not tracked at a } \\
\text { national level. }\end{array}$ \\
\hline Scholarship of engagement & $\begin{array}{l}\text { Until recently, CACSL provided } \\
\text { a blog identifying research } \\
\text { opportunities, although a } \\
\text { national tracking system does } \\
\text { not exist. Many Canadians } \\
\text { publish in journals based in the } \\
\text { United States. Engaged Scholar } \\
\text { Journal is a new venue for } \\
\text { Canadian work. }\end{array}$ & $\begin{array}{l}\text { Research is coordinated by a } \\
\text { national entity called ANUIES, } \\
\text { with representatives from } 180 \\
\text { public and private universities } \\
\text { attending the annual conference. }\end{array}$ \\
\hline International service-learning & $\begin{array}{l}\text { Many universities and colleges } \\
\text { offer international community } \\
\text { service-learning opportunities. } \\
\text { While some field schools occur } \\
\text { during reading break, many last } \\
\text { two to four weeks and may be } \\
\text { worth several courses. }\end{array}$ & $\begin{array}{l}\text { Limited opportunities exist } \\
\text { for international social service. } \\
\text { According to the Mexican } \\
\text { legislation, social service should } \\
\text { be performed for the benefit } \\
\text { of the society and the state } \\
\text { (Estudia, 2014). As such, social } \\
\text { service may only be performed } \\
\text { abroad for Mexican institutions } \\
\text { such as consulates, and } \\
\text { embassies. }\end{array}$ \\
\hline Research & $\begin{array}{l}\text { Professors present at national } \\
\text { and international conferences. } \\
\text { Publication opportunities exist } \\
\text { in community service-learning } \\
\text { or discipline-specific journals. }\end{array}$ & $\begin{array}{l}\text { Professors present at the } \\
\text { national Mexican conference: } \\
\text { their papers will only be } \\
\text { available on disc to those } \\
\text { attending the conference. } \\
\text { Publications are rare. }\end{array}$ \\
\hline
\end{tabular}

Engaged Scholar Journal: Community-Engaged Research, Teaching, and Learning 


\title{
Conclusion
}

The community engagement practices of Canada and Mexico are a study of opposites: while Mexico has a federally legislated requirement for community service for all post-secondary students and well-defined systems for universities, Canada, where the federal government's mandate does not include education, lacks a national agenda and the adoption of community service-learning ranges widely, from $25 \%$ of the student body in some universities to negligible engagement in others. The Mexican legislation responds to community need and facilitates students' sense of responsibility for the well-being of their community. Although the social service process in Mexico has flaws, including the lack of international placements, the consistent messaging of the importance of service and the well-developed support processes for community engagement provide a model that could guide the agenda of Canadian postsecondary institutions.

While Canadian alliances such as CACSL have promoted dialogue and exchanges between community partners and post-secondary institutions, the imperative for systematic student engagement and citizenship development has not been recognized at a political or national level. A national agenda could be developed, however, with assistance from several influential national bodies and associations, such as Universities Canada and CMEC. The conversation regarding a Canadian national vision for student and community engagement is very much in its infancy; we would benefit from looking at the social practices of our Mexican neighbour and building upon the strong components of their practices.

\begin{abstract}
About the Authors
Victoria Calvert (corresponding author) is a Professor at the Bissett School of Business, and the Community Service Learning Facilitator for Mount Royal University. She has served as an advisor for the Canadian Alliance for Community Service Learning (CACSL), Chaired the CACSL National Conference, and published extensively regarding community engagement. Email: vcalvert@mtroyal.ca

Halia Valladares Montemayor is the Dean of the Faculty of Business and Professional Studies at Capilano University. Halia has been a business professional in leadership positions for over two decades including being a University professor for the past 14 years. She earned her Doctoral Degree in Economics and Business Administration from Burgos University, Spain.
\end{abstract}




\section{References}

Andrews, P. A. (2007). Service-learning: Applications and research in business. Journal of Education for Business, 83(1), 10-26.

ANUIES (2012). Estadisticas de educacion superior, ciclo escolar 2010-2011. Elaboracion Annies, con datos del Formato 911.9A.

Astin, A. W., \& Sax, L. J. (1998). How undergraduates are affected by service participation. Journal of College Student Development, 39(2), 251-263.

Battistoni, R. M., Longo, N. V., \& Jayanandhan, S. R. (2009). Acting locally in a flat world: Global citizenship and the democratic practice of service-learning. Journal of Higher Education Outreach and Engagement, 13(2), 89-108.

Beatty, J. E. (2010). For which future? Exploring the implicit futures of service-learning. International Journal of Organizational Analysis, 18(2), 181-197.

Bloom, M. (2008). From the classroom to the community: Building cultural awareness in first semester Spanish. Language, Culture, and Curriculum, 2(2), 103-119.

Borden, A. W. (2007). The impact of service-learning on ethnocentrism in intercultural communications course. Journal of Experiential Education, 30(2), 171-183.

Bringle, R. G., \& Hatcher, J. A. (2005). Campus-community partnerships: The terms of engagement. Journal of Social Issues, 58(3), 503-5I6.

Bringle, R. G., \& Hatcher, J. A. (2010). International community service-learning. In R. G. Bringle, J.A. Hatcher, \& S. G. Jones (Eds.), International service learning: Conceptual frameworks and research (pp. 3-28). Sterling, VA: Stylus Publishing.

Brown, M. E., Trevino, L. K., \& Harrison, D. A. (2005). Ethical leadership: A social learning perspective for construct development and testing. Organizational Behavior and Human Decision Processes, 97(2), 117-134.

Brundiers, K., Wiek, A., \& Redman, C. L. (2010). Real-world learning opportunities in sustainability: from classroom into the real world. International Journal of Sustainability in Higher Education, 11(4), 308-324.

CACSL. (n.d.). History of CACSL.

Calvert, V. (2011). Service learning to social entrepreneurship: A continuum of action learning. Journal of Higher Education Theory and Practice, 11(2), 118-129.

Calvert, V., Jagoda, K., \& Jensen, L. (2011). Developing social entrepreneurs through business curriculum: A Canadian experience. IJIL International Journal of Innovation and Learning, 10(3), $215-225$

Calvert, V. (2012). Building sustainable Communities through service learning. The International Journal of Environmental, Cultural, Economic and Social Sustainability, 8, 65-84.

CMEC. (n.d.). About CMEC.

CMEC. (n.d.). Education in Canada: An overview.

Cornejo, A. (1992). El servicio social universitario en Mexico: Su filosofia, historia, marco juridico y vinculacion con la sociedad. Ed. Universidad de Guadalajara, Guadalajara, Jalisco, Mexico.

Dana, R., Murphy, J. W., \& Callaghan, K. A. (2010). Service-learning and social development in Latin American communities. International Journal of Environment, Cultural, Economic and Social Sustainability, 6(3), 123-131.

Engaged Scholar Journal: Community-Engaged Research, Teaching, and Learning 
Dees, J. G. (1998). The meaning of social entrepreneurship: Draft report for the Kauffman Center for Entrepreneurial Leadership. USA: Stanford University.

De Janasz, S. C., \& Whiting, V. R. (2009). Using service to transform learning re-scripted ABC's for our changing environment. International Journal of Organizational Analysis, 17(1), 60-75.

DeTray, S. (2005/2006). Service learning and sustainability. International Journal of Environmental, Cultural, Economic and Social Sustainability, 1, 51-56.

Dewey, J. (1933). How we think: A restatement of the relation of reflective thinking to the educative process. (2 ed.). Lexington, MA: Heath.

Duffy, J. (2008). Village empowerment: Service-learning with continuity, International Journal for service learning in Engineering, 3(2), 1-17.

Einfield, A., \& Collins, D. (2008). The relationships between service learning, social justice, multicultural competence, and civic engagement. Journal of College Student Development, 49(2), 95109.

Eisner, D., Grimm, R. T., Maynard, S., \& Washburn, S. (2009). The volunteer workforce, Stanford Innovation Review, Winter.

Escamilla, B. C. (2013). Acerca del Servicio Social, ANUIES.

Estudia (2014). El servicio social.

Eyler, J., \& Giles, D. (1999). Where's the learning in service-learning? (1st ed.). San Francisco, CA: Jones and Bartlett Publishers.

Flournoy, C. (2007). Investigative reporting and service learning. Journalism and Communication Educator, 62(1), 47-61.

Govekar, M. A., \& Rishi, M. (2007). Service learning: Bringing real-world education into the B-school classroom, Journal of Education for Business, 83(1), 3-10. Hartel, C. E. J. (2010). From the editors: International student's representation of global management issues, and education from a paradigm of human well-being. Academy of Management Learning and Education, 9, 585590.

Holland, B. A. (2001). A comprehensive model for assessing service-learning and community relationships, New Directions for Higher Education, 114 (Summer), 51-60.

Holland, B. (2005). Real change in higher education: Understanding differences in institutional commitment to engagement. In A. Kezar, T. Chambers, \& J. Burkhardt (Eds.), Higher Education for the Public Good: Emerging Voices from a National Movement (pp. 235-259). San Francisco, CA: Jossey-Bass Publishers.

Holsapple, M. A. (2012). Service learning and student diversity outcomes: Existing evidence and directions for future research, Michigan Journal of Community, 18(2), 5-18. How quality assurance works in Canada. (n.d.).

Kenworthy-U'Ren, A. L. (2008). A decade of service-learning: A review of the field ten years after JOBE's seminal issue, Journal of Business Ethics, 81(4), 811-822.

Kenworthy-U-Ren, A. \& Peterson, T. O. (2005). Service-learning and management education: Introducing the "We Care" approach, Academy of Management Learning \& Education, 4(3), 272277.

Lester, S. W., Tomkovick, C., Wells, T., Flunker, L., \& Kickul, J. (2005). Does service-learning add value? Examining the perspectives of multiple stakeholder, Academy of Management Learning \& Education, 4(3), 278-294. 
Lopez, Y. R., Muniz, R. L., Hernadez, M. C., Termini, C. B., Cervantes, M. L., \& Sarmiento, M. R. (1997). Caminos y rumbos del Servicio Social en Mexico, Universidad Iberoamericana, Universidad Intercontinental, Universidad Pedagogica Nacional, Mexico.

Lundy, B. L. (2007). Service learning in life-span developmental psychology: Higher exam scores and increased empathy. Teaching of Psychology, 34(1), 23-27. Mount Royal University. (n.d.). Community service learning.

Ramirez, J. M. (2012). El marco juridico del Servicio Social, Gaceta Medica de Mexico, 148, 284-91.

Rands, G., \& Starik M. (2009). The short and glorious history of sustainability in North American management education. In C. Wankel \& J. Stoner (Eds.), Management education for global sustainability (pp. 19-50). Charlotte, NC: Information Age Publishing.

Rasch, D., Murphy, J. W., \& Callaghan, K. A. (2010). Service-learning and social development in Latin American communities, International Journal of Environmental, Cultural, Economic and Social Sustainability, 6(3), 123-131.

Sheil, A., \& Bahk, C. M. (2010). Exploring the pedagogical outcomes of service learning in international public relations education, International Journal of Innovation and Learning, 7(3), 274-289.

Shrivastava, P. (2010). Pedagogy of passion for sustainability. Academy of Management Learning \& Education, 9(3), 443-455.

Statistics Canada. (2016). Postsecondary enrolments by institution type, registration status, province and sex (both sexes).

Taylor, T. P., \& Pancer, S. M. (2007). Community service experiences and commitment to volunteering, Journal of Applied Social Psychology, 37(2), 320-345.

Tomkovick, C., Lester, S. W., Flunker, L., \& Wells, T. A. (2008). Linking collegiate service learning to future volunteerism: Implications for nonprofit organizations, Nonprofit Management \& Leadership, 19(1), 3-26.

Tracey, P., \& Phillips, N. (2007). The distinctive challenge of educating social entrepreneurs: A postscript and rejoinder to the special issue on entrepreneurship education, Academy of Management Learning \& Education, 6(2), 264-271.

UAT (2014a). Reglamento de Servicio Social, Ley Organica, Universidad Autonoma de Tamaulipas, 29-34.

UAT (2014b). Sistema Integral de Servicio Social, Direccion de Servicio Social, Universidad Autonoma de Tamaulipas.

UJED (2014). Reglamento de Servicio Social, Universidad Juarez del Estado de Durango.

UNAM (2003). Guia de Primer ingreso y normatividad basica para el estudiante de la UNAM 20022003, Universidad Nacional Autonoma de Mexico.

UNAM (2014). Servicio Social, Direccion General de Orientacion y Servicios Educativos.

Universia (2014). Servicio Social. Retrieved from http://universitarios.universia.net.mx/voluntariadoservicio-social/servicio-social/

Universities Canada. (n.d.). Member Universities. Retrieved from https://www.univcan.ca/ universities/member-universities/

University of Alberta. (n.d.). Campus sustainability initiative: Community service-learning. Retrieved from https://www.ualberta.ca/sustainability/education/learning-programs

University of Alberta. (n.d.). Community service-learning.

University of British Columbia. (n.d.). Learning exchange.

Engaged Scholar Journal: Community-Engaged Research, Teaching, and Learning 
University of Ottawa. (n.d.). Community service learning. Vézina, M., \& Crompton, S. (2012). Volunteering in Canada.

Zlotowski, E. (1996). Linking service-learning and the academy. Change, 28(1), 21-27. 